\title{
In vitro anticancer and hepatoprotective activities of Artocarpus gomezianus
}

\section{S.J. PRASHANTH, D. SURESH, V.H. POTTY AND P. SADANANDA MAIYA}

See end of the paper for authors' affiliation

Correspondence to : D. SURESH

Department of Studies and Research in Chemistry, Tumkur University, TUMKUR (KARNATAKA) INDIA Email: pbdsuresh@gmail.com

\begin{abstract}
The study aimed at assessing the potency of hydroalcoholic extracts of various parts of Artocarpus gomezianus against cancer using in vitro cell lines. MCF-7, HepG2, HeLa, PC3, A549 and Vero cell lines were employed for the assessment. The ability of extracts to exert toxic insult on cancer cells has been the basis of anticancer activity. Among the extracts from different parts of Artocarpus, AGR was found to be toxic with average CTC50 values of $110 \mu \mathrm{g} / \mathrm{ml}$. With regard to A549 cell lines, AGR was found to be highly toxic with value of CTC50 $273 \mu \mathrm{g} / \mathrm{ml}$, respectively. The results clearly demonstrate that the extracts of selected plants exert potential anticancer activity. In vitro hepatoprotective activity of the plant extracts was studied by employing primary rat hepatocytes. Our results indicate that the drug Silymarin was found to exhibit $96 \%$ protection againstParacetamol induced toxicity in Hep G2 cells at the tested concentration of $250 \mathrm{mg} / \mathrm{ml}$. Among the different extracts of Artocarpus gomezianus, AGF, AGR and AGA were found to have comparatively lower protective power than Silymarin. In paracetamol induced toxicity of primary rat hepatocytes, the drug Silymarin was found to exhibit $85.28 \%$ protection againstParacetamol induced toxicity in Primary rat hepatocytes at the tested concentration of $250 \mathrm{mg} / \mathrm{ml}$. It was found that extracts of Artocarpus gomezianus, considerably lesser activity when compared to the standard silymarin. The extract of Artocarpus gomezianus may be considered for further studies as they appear to be very promising antiproliferative agents.
\end{abstract}

How to cite this paper : Prasahnth, S.J., Suresh, D., Potty, V.H. and Maiya, P. Sadananda (2014). In vitro anticancer and hepatoprotective activities of Artocarpus gomezianus. Internat. J. Med. Sci., 7(1\&2) : 18-23.

\section{KEY WORDS :}

Artocarpus gomezianus, Plant extracts, Anticancer, Hepatoprotective activity 